\title{
Strategies in the cyclopentadienyl chemistry of p-block elements*
}

\author{
Peter Jutzi \\ University of Bielefeld, Department of Chemistry, Universitätsstr. 25, \\ D-33615 Bielefeld, Germany
}

\begin{abstract}
Synthetic strategies in the cyclopentadienyl (Cp) chemistry of the groups 13-15 elements, are based on the following phenomena: (1) low barriers for haptotropic and dyotropic shifts, for sigmatropic rearrangements, and for other types of Cp migration; (2) stabilization of elements in their low-oxidation state by $\pi$-complexation; (3) tuning of steric and electronic effects by suitable ring substituents; and (4) easy homolytic and heterolytic cleavage of El-C(Cp) bonds. These strategies are applied to: (a) the formation of a $\mathrm{Si}_{2} \mathrm{Me}_{4}$ doubly bridged dicyclopentadienyl cobalt complex, (b) the chemistry of half-sandwich $\left[\mathrm{Me}_{5} \mathrm{C}_{5} \mathrm{Ga}\right]$ and sandwich $\left[\left(\mathrm{Me}_{5} \mathrm{C}_{5}\right)_{2} \mathrm{Si}\right]$ complexes, (c) the formation of $\mathrm{P}_{6}$, (d) the deposition of $\mathrm{Al}, \mathrm{Ga}$, $\mathrm{Si}, \mathrm{Ge}$, and As from respective $\mathrm{Cp}-\mathrm{El}$ precursor molecules, and (d) the "dynamic covalent chemistry" in ferrocenylgallium(III) compounds.
\end{abstract}

\section{INTRODUCTION}

Shortly after the fundamental discovery of transition-metal compounds containing $\pi$ - or $\sigma$-bound cyclopentadienyl $(\mathrm{Cp})$ ligands [1,2], structurally comparable compounds with p-block elements as central units have been described, namely stannocene, $\mathrm{Sn}\left(\pi-\mathrm{C}_{5} \mathrm{H}_{5}\right)_{2}$ [3], and trialkyl(cyclopentadienyl)silanes, $\mathrm{R}_{3} \mathrm{Si}\left(\sigma-\mathrm{C}_{5} \mathrm{H}_{5}\right)$ [4]. As a result of many experimental and theoretical studies from the last decades, the $\mathrm{Cp}$ chemistry of p-block elements is meanwhile well understood. It is the aim of this article to describe basic features of structure, bonding, and reactivity of $\mathrm{Cp}$ compounds of groups 13-15 elements and to extract from this information $\mathrm{Cp}$-specific phenomena, which have become important in synthetic strategies.

\section{$\pi$-CYCLOPENTADIENYL COMPLEXES}

$\pi$-Cyclopentadienyl complexes of p-block elements have been described in detail in recent reviews [5-8]. Concerning a qualitative picture of structure and bonding, electron-counting, and the octet rule may be used for classification. In each class of $\pi$-complexes, the respective p-block element fragments are isoelectronic and isolobal, and the number of valence electrons (VEs) in a $\pi$-cyclopentadienyl fragment always corresponds to that of a $\mathrm{Cp}$ radical (5 electrons).

\section{Half-sandwich complexes}

In the group of half-sandwich complexes, Cp compounds with 8, 10, and 12 VEs have to be discussed. As described in Scheme 1, the 8 VE situation corresponds to a $\eta^{5}$-structure, in which all $5 \mathrm{Cp}$-centered

\footnotetext{
*Plenary lecture presented at the $\mathrm{XX}^{\text {th }}$ International Conference on Organometallic Chemistry (ICOMC), Corfu, Greece, 7-12 July 2002. Other presentations are published in this issue, pp. 421-494.
} 
electrons are involved in bonding to the El fragment. According to the MO-based rules of Mingos, Rudolph, and Williams, these half-sandwich compounds are described as nido-clusters.
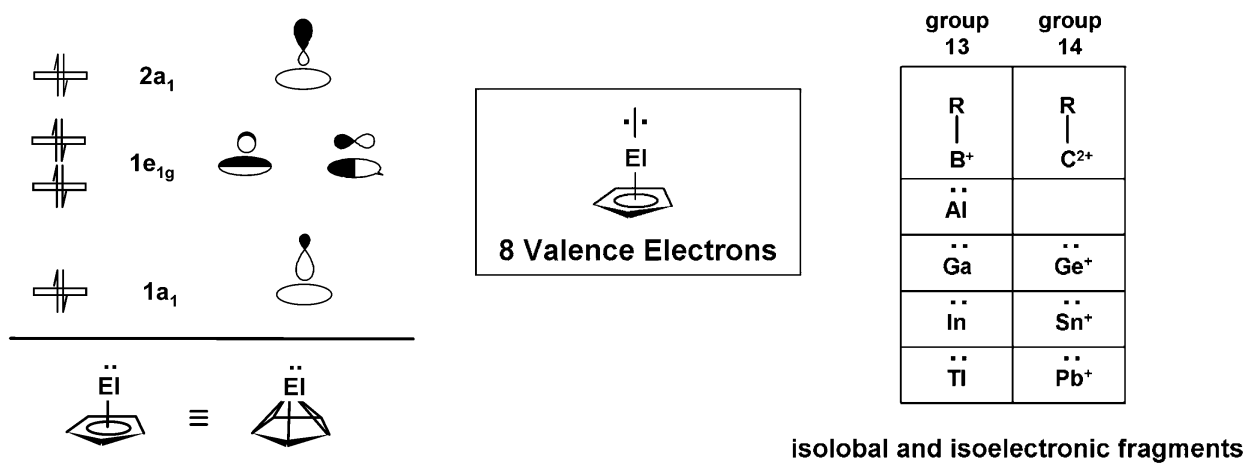

Scheme 1

In the class of half-sandwich complexes of p-block elements, it is strategically important that these elements can be stabilized in their low-oxidation state. A breakthrough in the chemistry of group 13 elements was the preparation of $\mathrm{Me}_{5} \mathrm{C}_{5} \mathrm{Al}(\mathrm{I})$ and $\mathrm{Me}_{5} \mathrm{C}_{5} \mathrm{Ga}(\mathrm{I})$ in the group of Schnöckel $[9,10]$. These compounds have been obtained by the reaction of metastable $\mathrm{Al}(\mathrm{I}) \mathrm{Cl}$ or $\mathrm{Ga}(\mathrm{I}) \mathrm{Cl}$ solutions with $\mathrm{Me}_{5} \mathrm{C}_{5}$ transfer agents. More convenient synthetic routes have been described some years later [11,12]. A very recent review informs about the synthesis, structure, and chemistry of the pentamethylcyclopentadienyl $\left(\mathrm{Cp}^{*}\right)$ complexes of the monovalent group 13 elements [13]. The chemistry is dominated by the homolytic and heterolytic $\mathrm{Cp}^{*}$-El bond cleavage, by the donor function of the El-centered lonepair, and by a carbene-like reactivity. The application of $\mathrm{Cp}^{*} \mathrm{Al}$ and of $\mathrm{Cp} * \mathrm{Ga}$ as ligands in transitionmetal chemistry turns out to be very promising [13].

The 10 VE situation requires a $\eta^{2 / 3}$-structure, as described in Scheme 2; only three of the five Cp electrons are involved in the bonding to the El fragment. This bonding situation is documented for the solid state of several compounds by X-ray crystal structure investigations [5]. In solution, such compounds are highly fluxional due to fast haptotropic rearrangements, even at low temperatures.

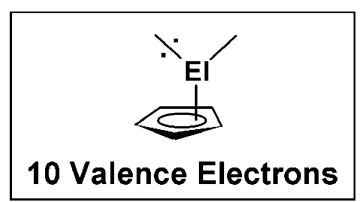

\section{Scheme 2}

The qualitative character of a bonding concept based on electron-counting implies that there exist several exceptions, especially in the $\mathrm{Cp}$ chemistry of the group 13 elements (e.g., the structures of $\mathrm{H}_{5} \mathrm{C}_{5} \mathrm{GaEt}_{2}$ [14], $\left(\mathrm{Me}_{3} \mathrm{H}_{2} \mathrm{C}_{5}\right)_{3} \mathrm{Al}$ [15], and $\left(\mathrm{H}_{5} \mathrm{C}_{5}\right)_{2} \mathrm{AlMe}$ [15]). Of course, much better understanding of structure and bonding is gained with the help of high-level calculations. 
In the class of $\mathrm{Cp}$-El compounds with $12 \mathrm{VEs}$, the electron-counting does not help to predict the structure. Some compounds prefer a $\pi$ - and others a $\sigma$-structure. The transition from $\sigma$ - to $\pi$-structures is nicely documented by X-ray crystal structure investigations in the series of the comparable compounds $\left[\left(\mathrm{Me}_{2} \mathrm{HC}\right)_{4} \mathrm{HC}_{5}\right] \mathrm{ElCl}_{2}(\mathrm{El}=\mathrm{P}, \mathrm{As}, \mathrm{Sb}, \mathrm{Bi})[16]$. Once again, such compounds are highly fluxional in solution.

\section{Sandwich complexes}

The bonding in sandwich complexes with 12 and 14 VEs is described in Scheme 3 on the basis of electron-counting rules and MO schemes. It is evident from these descriptions that two electron pairs remain in nonbonding situations in the $12 \mathrm{VE}$ species and also in the $14 \mathrm{VE}$ species; in the last series, the so called "lone pair" of the groups 14 or 15 element corresponds to the $2 \mathrm{a}_{1}$ orbital, and the bent $\eta^{2 / 3}$-structure is energetically favored. In the series of the $12 \mathrm{VE}$ species, the metallocenes of beryllium and of magnesium are included for comparison; in these sandwich complexes as well as in dicyclopentadienyl-aluminum cations, the structure is determined by covalent interactions between the $\mathrm{Cp}$ and the El unit. Note that in the case of the comparable bis(pentamethylcyclopentadienyl)boronium cation, a $\eta^{5}$-bonding to one $\mathrm{Cp}$ ring and a $\eta^{1}$-bonding to the other one is energetically preferred $[17,18]$.
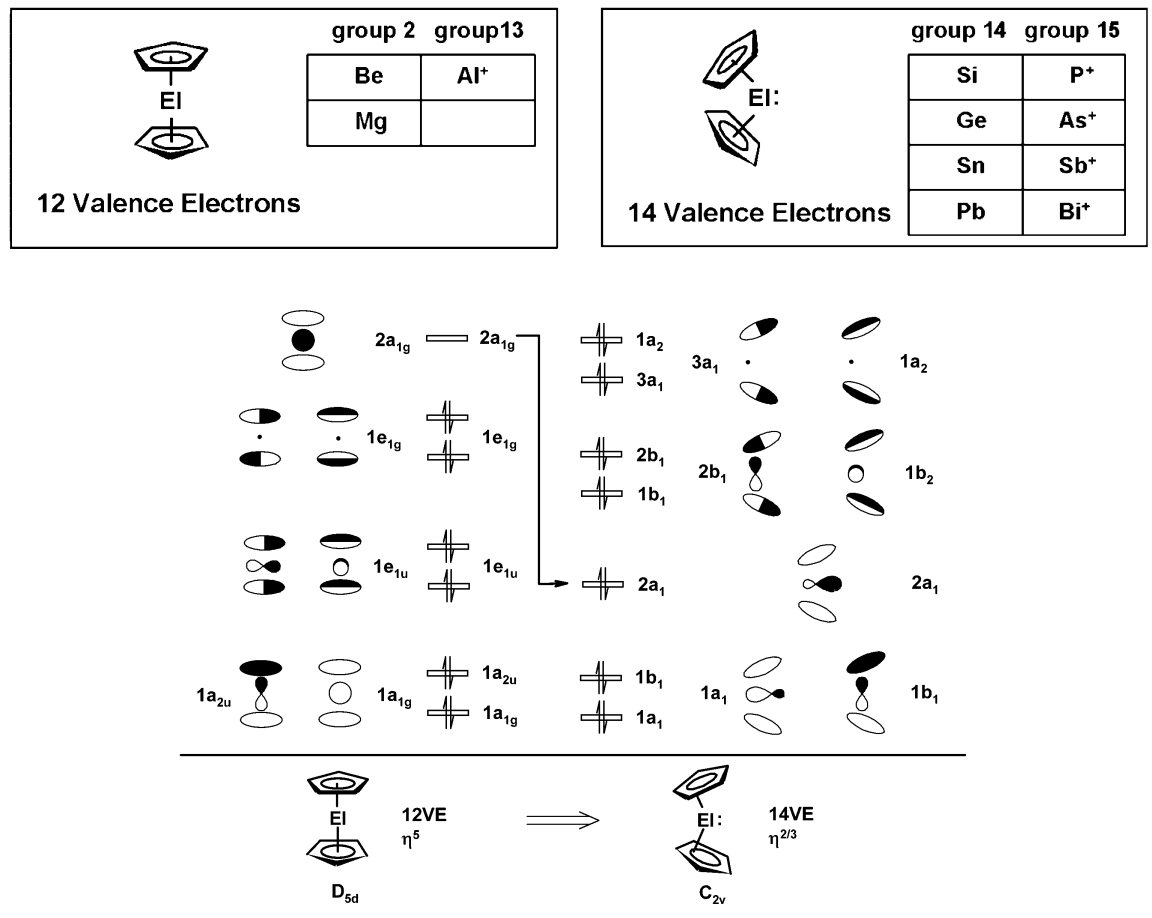

Scheme 3

A breakthrough in the chemistry of the group 14 elements was the preparation of the sandwich complex decamethylsilicocene, $\left(\mathrm{Me}_{5} \mathrm{C}_{5}\right)_{2} \mathrm{Si}$, containing divalent silicon [19]. Scheme 4 informs about the development of the $\pi$-complex chemistry of silicon and of the class of monomeric compounds containing divalent silicon as the central atom.

The sandwich complexes $\left(\mathrm{H}_{2} \mathrm{C}_{2} \mathrm{~B}_{9} \mathrm{H}_{9}\right)_{2} \mathrm{Si}$ [20], [ $\left(\mathrm{Me}_{3} \mathrm{Si}_{2} \mathrm{C}_{2} \mathrm{~B}_{4} \mathrm{H}_{4}\right]_{2} \mathrm{Si}$ [21], and $\left(\mathrm{Me}_{5} \mathrm{C}_{5}\right)_{2} \mathrm{Si} \mathrm{[19]}$, were all published in 1986. After the successful synthesis of $\left(\mathrm{Me}_{5} \mathrm{C}_{5}\right)_{2} \mathrm{Si}$, the area of stable silicon(II)compounds has shown an interesting further development. Meanwhile, at least three classes of compounds are present in the literature: one class containing compounds with a hyper-coordinated 

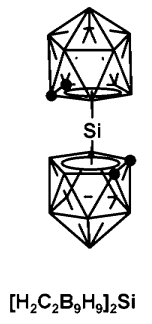

Hawthorne 1986

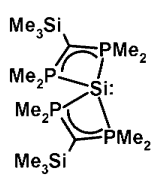

Karsch 1990

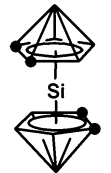

$\left[\left(\mathrm{Me}_{3} \mathrm{Si}\right)_{2} \mathrm{C}_{2} \mathrm{~B}_{4} \mathrm{H}_{4}\right]_{2} \mathrm{Si}$

Hosmane 1986<smiles>[X]c1ccccc1N1[Si]N([R])[Si]1</smiles>

Denk, West 1994 Lappert 1995 Heinicke 1998

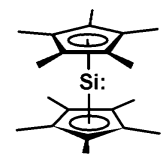

Jutzi 1986

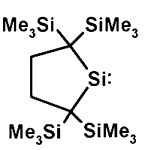

Kira 1999

\section{Scheme 4}

silicon center- $\left(\mathrm{Me}_{5} \mathrm{C}_{5}\right)_{2} \mathrm{Si}$ [19] and $\left[\mathrm{Me}_{2} \mathrm{P}-\mathrm{C}\left(\mathrm{SiMe}_{3}\right)-\mathrm{PMe}_{3}\right]_{2} \mathrm{Si}$ [22]—and two classes containing compounds with dicoordinated silicon centers- $\mathrm{R}_{2} \mathrm{Si}[23,24]$ - (see Scheme 4).

Synthesis, structure, bonding, and chemistry of decamethylsilicocene are described in detail in a very recent review [25]. This compound shows the reactivity of a nucleophilic silylene due to the fact that the $\pi$-bonded $\mathrm{Cp}^{*}$ ligands easily rearrange to $\sigma$-bonded substituents. The migratory aptitude and the leaving group character of the $\mathrm{Cp}^{*}$ units (see general discussion in later sections) are the reason for sometimes rather surprising reaction pathways. For illustration, the reaction of $\left(\mathrm{Me}_{5} \mathrm{C}_{5}\right)_{2} \mathrm{Si}$ with the group 13 element trichlorides is presented in Scheme 5: $\mathrm{Cp}^{*}$ transfer is observed in the reactions with $\mathrm{BCl}_{3}$ and $\mathrm{AlCl}_{3}$, and reduction takes place in the reactions with $\mathrm{GaCl}_{3}$ and $\mathrm{InCl}_{3}$ [26].

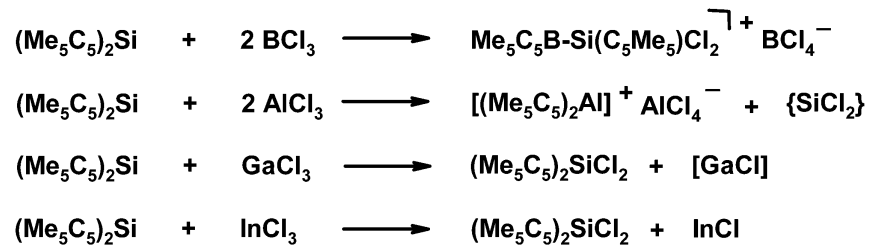

Scheme 5

Another illustrative example for a surprising reaction pathway is given in Scheme 6. The unique cluster compound $\mathrm{SiAl}_{14}\left(\mathrm{C}_{5} \mathrm{Me}_{5}\right)_{6}$ is formed in the reaction of $\left(\mathrm{Me}_{5} \mathrm{C}_{5}\right)_{2} \mathrm{Si}$ with a metastable $\mathrm{Al}(\mathrm{I}) \mathrm{Cl}$ solution [27].

$$
\left(\mathrm{Me}_{5} \mathrm{C}_{5}\right)_{2} \mathrm{Si}+\mathrm{AICl} \longrightarrow \mathrm{SiAl}_{14}\left(\mathrm{C}_{5} \mathrm{Me}_{5}\right)_{6}+\mathrm{Si}\left(\mathrm{AICl}_{2}\right)_{4} \cdot 4 \mathrm{Et}_{2} \mathrm{O}+\mathrm{Me}_{5} \mathrm{C}_{5} \mathrm{AlCl}_{2} \cdot \mathrm{Et}_{2} \mathrm{O}
$$

Scheme 6

\section{$\sigma$-CYCLOPENTADIENYL COMPOUNDS}

A rather weak carbon-element bond is a characteristic feature of the $\sigma$-cyclopentadienyl $(\mathrm{Cp})$ compounds of the groups 13-15 elements. As a result, several types of migrating processes are observed; they are shown in Scheme 7 and include sigmatropic rearrangements, dyotropic rearrangements, 1,2-migration 
and redistribution reactions. It will be demonstrated that one can make use of the migratory aptitude of $\mathrm{Cp}-\mathrm{El}$ compounds in synthetic strategies.

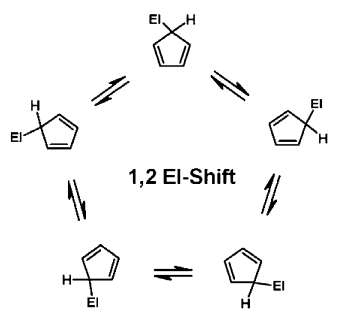

Sigmatropic Rearrangements

Scheme 7

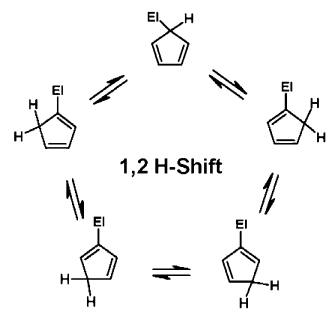

Dyotropic Rearrangements

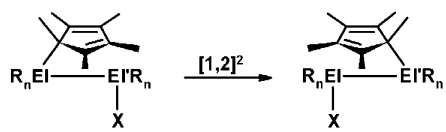

1,2-Migration

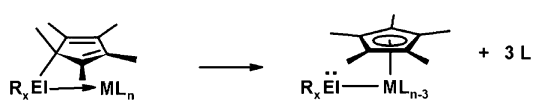

Redistribution

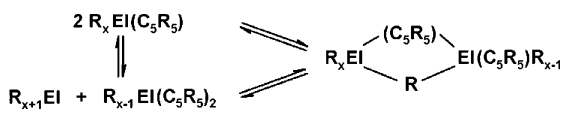

\section{Sigmatropic rearrangements}

The fluxionality of $\sigma$-Cp-El compounds on the basis of 1,2El- and 1,2H-shifts has been discussed in the literature in detail [28] and seems to be well understood. Cyclopentadienylsilicon compounds have been intensively studied concerning their fluxional behavior in the context with their application as ligands or as ligand precursors in transition-metal chemistry. The regioselective $\mathrm{Si}-\mathrm{C}$ bond formation allows the preparation of tailor-made Cp ligands [29]; this is demonstrated with two illustrative examples, which are depicted in Scheme 8.

In Fryzuk's work, the 1,1-disilyl substituted cyclopentadiene $\mathrm{C}_{5} \mathrm{H}_{4}\left[\mathrm{SiMe}_{2}\left(\mathrm{CH}_{2} \mathrm{PR}_{2}\right)\right]_{2}$ is regioselectively transformed to the 1,3-disilyl substituted lithium cyclopentadienide, which after reaction with $\mathrm{ZrCl}_{4}$ gives the corresponding zirconium complex [30]. In our work, the twofold disilanyl bridged dicyclopentadiene $\left[\mathrm{C}_{5} \mathrm{H}_{4}\left(\mathrm{Si}_{2} \mathrm{Me}_{4}\right)\right]_{2}$ reacts regioselectively with $\mathrm{Co}_{2}(\mathrm{CO})_{8}$ to a "paracyclopentadienylophane" complex, in which two $\mathrm{CpCo}(\mathrm{CO})_{2}$ units are connected by two disilanyl bridges [31].
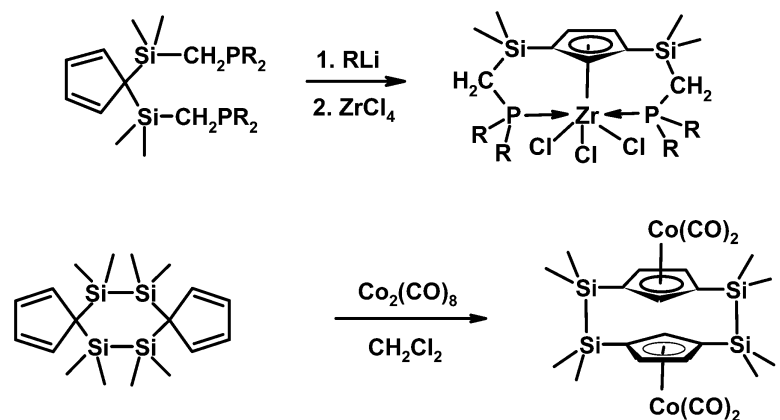

Scheme 8 
The stepwise silatropic processes in $\left[\left(\mathrm{C}_{5} \mathrm{H}_{4}\left(\mathrm{Si}_{2} \mathrm{Me}_{4}\right)\right]_{2}\right.$ are described in Scheme 9. The deprotonated 1,1-1,2-isomer as well as the doubly deprotonated 1,2-1,2-isomer are useful ligands in transitionmetal chemistry [32]. So far, the 1,3-1,3-isomer could only be generated in the form of the neutral $\mathrm{Co}(\mathrm{CO})_{2}$-complex and not in the form of the corresponding salt.

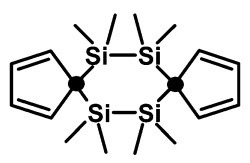

[1.1-1.1-Isomer]

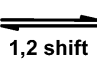

1,2 shift

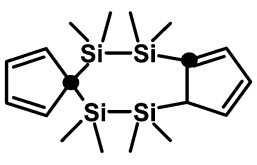

[1.1-1.2-Isomer]

$\overline{1,2 \text { shift }}$

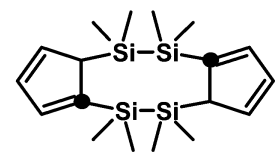

[1.2-1.2-Isomer]

$+2 \mathrm{R}^{-}$ $-2 \mathrm{RH}$
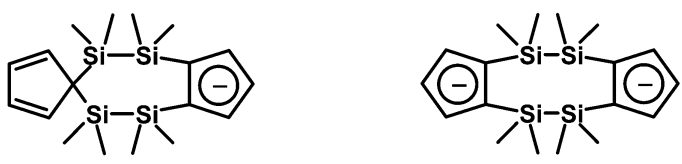

Scheme 9

\section{Dyotropic rearrangements}

A dyotropic rearrangement is an uncatalyzed process in which two $\sigma$-bonds simultaneously migrate intramolecularly. We have not performed detailed mechanistic studies, so we refer to this process in a more general way with the term $[1,2]^{2}$, indicating two 1,2-migrations. In Scheme 10, three examples from decamethylsilicocene $\left(\mathrm{Cp}_{2}{ }_{2} \mathrm{Si}\right)$ chemistry are described, where $[1,2]^{2}$-migrations are involved in the reaction sequence. In the first example, a $\mathrm{Cp}^{*}$ group migrates from silicon to boron and a halogen substituent from boron to silicon [26]. The second example describes a Si-Cp*/Zn-alkyl interchange [33]. In the final reaction sequence, two steps are involved with Si-Cp*/C-S interchange processes; the result of the reaction of $\mathrm{Cp}_{2}^{*} \mathrm{Si}$ with $\mathrm{CS}_{2}$ is rather surprising [34]. 

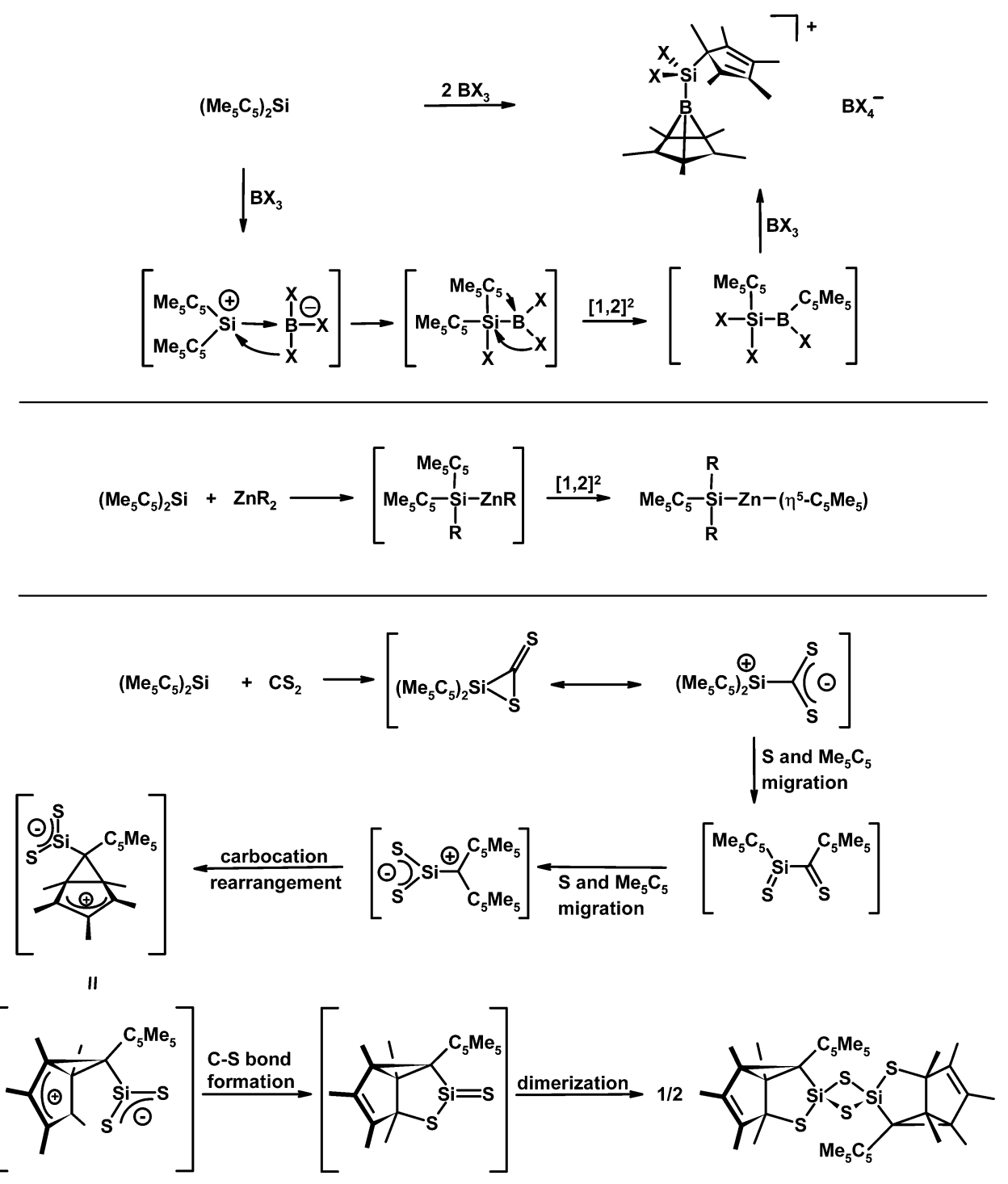

Scheme 10

\section{1,2-Migration}

The "1,2-migration" process is understood as the transformation of a transition-metal complex containing a Cp-substituted group 15 element compound as neutral ligand into a $\eta^{5}$-Cp transition-metal complex possessing a covalent El-transition-metal bond. Such migrations rely on the weakness of the Cp-El bond and are often observed in the chemistry of $\mathrm{Cp}^{*}$-substituted phosphorus compounds [5]. Typical examples are shown in Scheme 11. Thus, the diphosphene $\mathrm{Cp} * \mathrm{P}=\mathrm{PMes} *$ reacts with $\left(\mathrm{CH}_{3} \mathrm{CN}\right)_{3} \mathrm{Cr}(\mathrm{CO})_{3}$ or with $\mathrm{R}_{3} \mathrm{PNi}\left(\mathrm{C}_{2} \mathrm{H}_{4}\right)_{2}$ to give the chromio- and the nickela-substituted diphosphenes $\mathrm{Cp} *(\mathrm{CO})_{3} \mathrm{Cr}$ $\mathrm{P}=\mathrm{PMes} *$ and $\mathrm{Cp} *\left(\mathrm{PR}_{3}\right) \mathrm{Ni}-\mathrm{P}=\mathrm{PMes} *$, respectively [35,36]. The phosphinidene complex $\mathrm{Cp} * \mathrm{P}\left[\mathrm{W}(\mathrm{CO})_{5}\right]_{2}$ reacts by thermal activation to the cluster compound $\left[(\mathrm{CO})_{5} \mathrm{~W}-\mathrm{P}\right]_{2}$ $\left[\mathrm{Cp} *(\mathrm{CO})_{2}(\mathrm{H}) \mathrm{W}\right]\left[\mathrm{W}(\mathrm{CO})_{4}\right]$. The complexes $\mathrm{Cp} *(\mathrm{CO})_{2} \mathrm{~W} \equiv \mathrm{P}\left[\mathrm{W}(\mathrm{CO})_{5}\right]$ and $\mathrm{P}\left[\mathrm{W}(\mathrm{CO})_{5}\right]_{2}$ are formed as reactive intermediates, which combine under uptake of a hydrogen atom, presumably from the solvent [37]. The latter intermediate arises by homolytic cleavage of a Cp*-P bond (vide infra) [5]. 

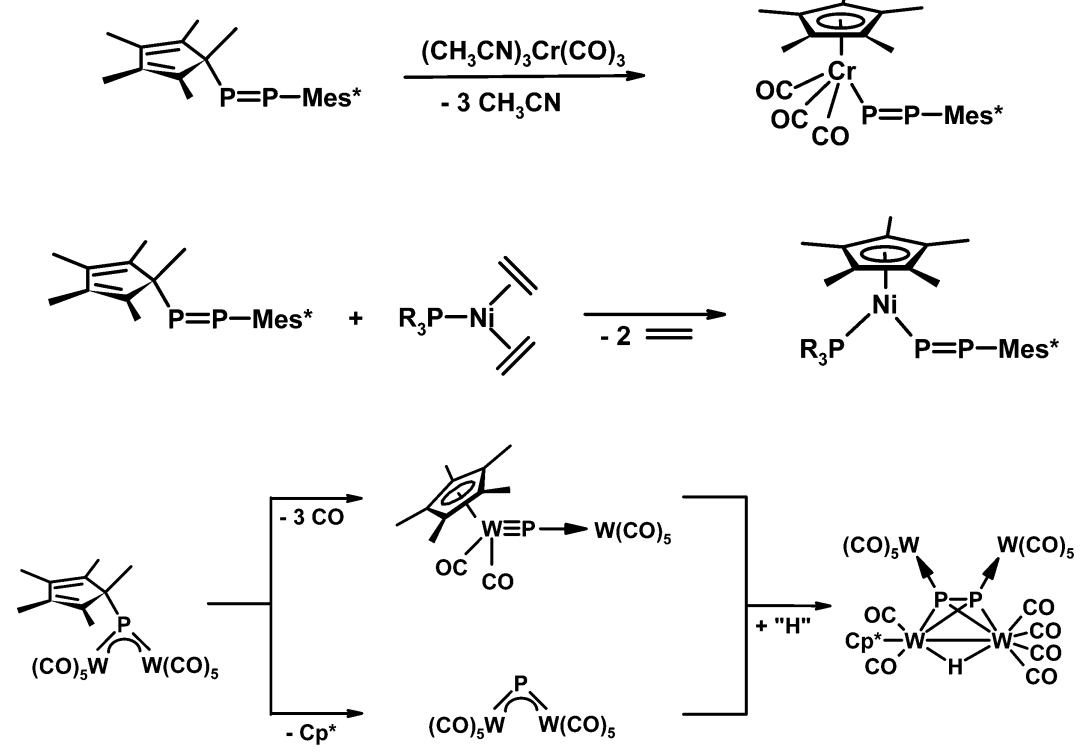

Scheme 11

\section{Redistribution reactions}

Cp-ligand exchange reactions are often observed in the chemistry of the heavier groups 13-15 elements. In group 13 element chemistry it depends on the type of the $\mathrm{Cp}$ substituent, on the nature of the organic group R, and on the phase (solid, liquid, solution), whether a heteroleptic compound of the type CpElR ${ }_{2}$ exists as a single compound or undergoes a series of ligand redistribution reactions to form a mixture of $\mathrm{CpElR}_{2}, \mathrm{Cp}_{2} \mathrm{ElR}, \mathrm{Cp}_{3} \mathrm{El}$, and $\mathrm{ElR}_{3}$ compounds. Thus, ligand redistribution can be exploited as a synthetic tool. This phenomenon has been studied in detail in aluminum and gallium chemistry and has been described in very recent publications $[15,38,39]$.

\section{Homolytic Cp-El bond cleavage}

The easy thermally and photochemically initiated $\mathrm{Cp}$-El bond cleavage has been used as a strategy to prepare novel types of compounds and to deposit groups 13-15 elements in thin film or related technologies [5]. Some examples are presented in Schemes 12 and 13. Irradiation of the pentamethylcyclopentadienyl $\left(\mathrm{Cp}^{*}\right)$-substituted diphosphene $\mathrm{Cp}^{*}{ }_{2} \mathrm{P}_{2}$ led to the butterfly compound $\mathrm{Cp}^{*}{ }_{2} \mathrm{P}_{4}$ and finally to the $\mathrm{P}_{4}$ molecule [40]. The $\mathrm{Cp}^{*}$-substituted cyclotriphosphane $\mathrm{Cp}_{3}{ }_{3} \mathrm{P}_{3}$ was converted to the bicyclic hexaphosphane $\mathrm{Cp}^{*}{ }_{4} \mathrm{P}_{6}$ by thermal treatment in benzene solution; the latter compound could be transferred to the tricyclic hexaphosphane $\mathrm{Cp}_{2}{ }_{2} \mathrm{P}_{6}$ in boiling xylene [41]. The dihydrobenzvalene structure of this compound initiated further cleaving reactions with the aim to prepare a novel allotrope of phosphorus, namely $\mathrm{P}_{6}$. Finally, this experiment could be successfully performed under special mass spectrometric conditions (neutralization-reionization technique) (Scheme 12) [42].

Silicon and germanium compounds with pentamethylcyclopentadienyl and also partially methylated cyclopentadienyl substituents have been used in the CVD (chemical vapor deposition) process for the preparation of silicon- and germanium-containing materials [43-45]. An only low carbon content is the result of a rather selective El-C(Cp*) bond cleavage. The decomposition pathways have been studied by in situ mass spectrometry. In the case of the pentamethylcyclopentadienyl-substituted substrates, the compounds pentamethylcyclopentadiene and tetramethylfulvene are the sole organic decomposition products. 

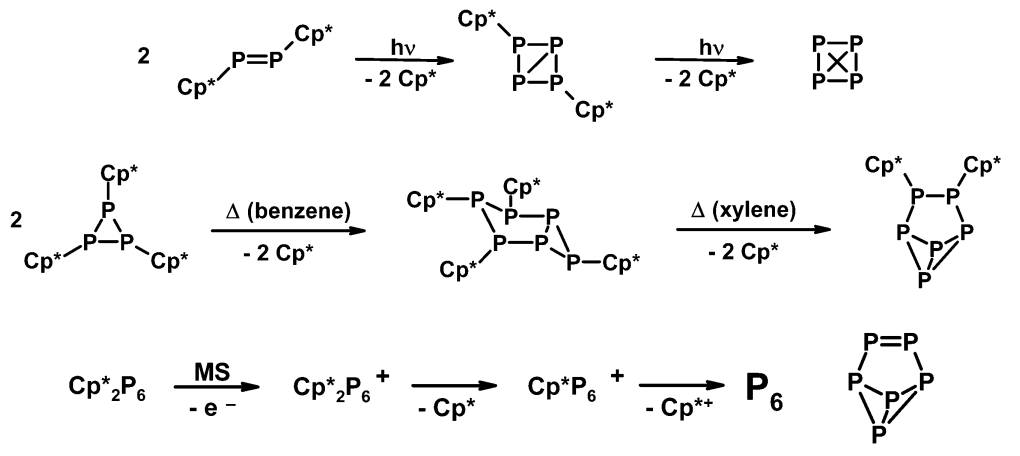

\section{Scheme 12}

Dimethylaminoethyl-cyclopentadienyl compounds of aluminum and gallium have been used as precursors for the deposition of thin films of Al and Ga, respectively (Scheme 13) [46,47]. The dimethylamino group prevents oligomerization by an intramolecular coordination to the group 13 element. Interestingly, the protonated $\mathrm{Cp}$-substituent is the main organic product regained after the thermal decomposition process. The lability of the $\mathrm{El}-\mathrm{C}(\mathrm{Cp})$ bond is nicely demonstrated by the photochemical decomposition of the dihydrido gallium species $\left(\mathrm{Me}_{2} \mathrm{NCH}_{2} \mathrm{CH}_{2}\right) \mathrm{H}_{4} \mathrm{C}_{5} \mathrm{GaH}_{2}$ in benzene solution [47].

Scheme 13
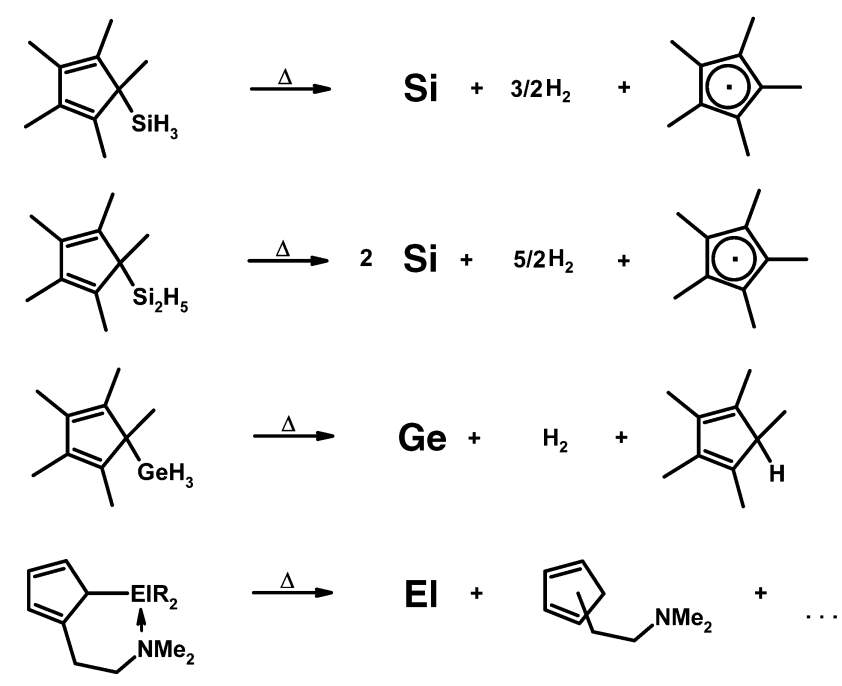

$\mathrm{El}=\mathrm{Al}, \mathbf{G a}$

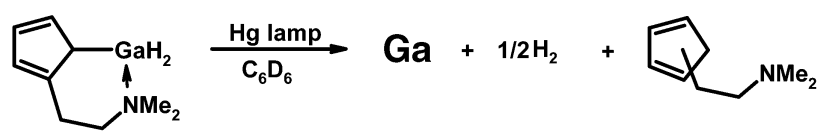

\section{FERROCENYLGALLIUM(III) CHEMISTRY}

The weakness of the $\mathrm{C}$ (ferrocenyl)-Ga bond is the reason for redistribution reactions in ferrocenylgallium(III) compounds, comparable to the situation in $\sigma$-cyclopentadienyl gallium(III) species (mentioned above). As exemplified in Scheme 14 for the case of the corresponding pyridine complexes, $1,1^{\prime}$-bis(dimethylgallyl)ferrocene can be tranferred into trimethylgallium and the threefold ferrocene1,1'-diyl-substituted digallium compound $\left[\mathrm{Fe}\left(\mathrm{C}_{5} \mathrm{H}_{4}\right)_{2}\right]_{3} \mathrm{Ga}_{2}$, possessing a so-far-unknown "carousel" 


\section{Scheme 14}

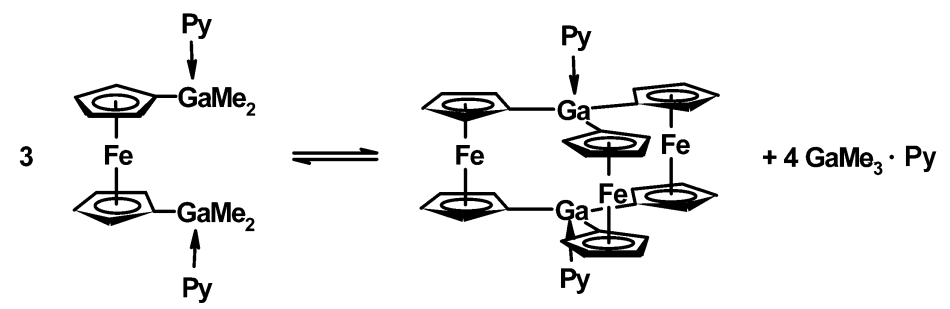

structure [48]. The twofold ferrocene-diyl substituted digallium compound $\left[\mathrm{Fe}\left(\mathrm{C}_{5} \mathrm{H}_{4}\right)_{2}\right]_{2}(\mathrm{GaMe})_{2}$ is an isolable intermediate. The observed reversibility of this reaction sequence presumably is a prerequisite for the formation of the carousel structure. Thus, ferrocenylgallanes, and more generally also other ferrocenyl-groups 13-15 element compounds, might play an important role in a strategy called "dynamic covalent chemistry" [49].

\section{ACKNOWLEDGMENTS}

We thank the Deutsche Forschungsgemeinschaft, the Fonds der Chemischen Industrie, and the University of Bielefeld for their financial support. The author would like to express his sincere thanks to the collaborators cited in the references for their extensive work and to Dr. A. Mix for preparing the drawings.

\section{REFERENCES}

1. (a) T. J. Kealy and P. L. Pauson. Nature 168, 1039 (1952); (b) S. A. Miller, J. A. Tebboth, J. F. Tremane. J. Chem. Soc. 632 (1952); (c) G. Wilkinson, M. Rosenblum, C. Whiting, R. B. Woodward. J. Am. Soc. 74, 2125 (1952); (d) E. O. Fischer and W. Pfab. Z. Naturforsch. 7b, 377 (1952).

2. G. Wilkinson and T. S. Piper. J. Inorg. Nucl. Chem. 2, 32 (1956).

3. E. O. Fischer and H. Grubert. Z. Naturforsch. 11b, 423 (1956).

4. H. P. Fritz and C. G. Kreiter. J. Organomet. Chem. 4, 313 (1965).

5. P. Jutzi and G. Reumann. J. Chem. Soc. Dalton Trans. 2237 (2000).

6. P. Jutzi and N. Burford. Chem. Rev. 99, 969 (1999).

7. P. Jutzi and N. Burford. Synthesis, Reactivity and Application in Metallocenes, A. Togni and R. L. Halterman (Eds.), Vol. 1, pp. 3-54, Wiley-VCH, Weinheim (1998).

8. P. Jutzi. Chem. Unserer Zeit 33, 342 (1999).

9. C. Dohmeier, C. Robl, M. Tacke, H. Schnöckel. Angew. Chem. 103, 594 (1991); Angew. Chem., Int. Ed. Engl. 30, 564 (1991).

10. D. Loos and H. Schnöckel. J. Organomet. Chem. 463, 37 (1993).

11. S. Schulz, H. W. Roesky, H. J. Koch, G. M. Sheldrick, D. Stalke, A. Kuhn. Angew. Chem. 105, 1828 (1993); Angew. Chem., Int. Ed. Engl. 32, 1729 (1993).

12. (a) P. Jutzi, B. Neumann, G. Reumann, H.-G. Stammler. Organometallics 17, 1305 (1998); (b) L. O. Schebaum and P. Jutzi. J. Organomet. Chem. (2002).

13. L. O. Schebaum and P. Jutzi. In Group 13 Chemistry - From Fundamentals to Applications. P. J. Shapiro and D. A. Atwood (Eds.), ACS Symposium Series 822, pp. 16-30, American Chemical Society, Washington, DC (2002).

14. O. T. Beachly, Jr., T. D. Getmann, R. Kirss, R. B. Hallock, W. C. Hünter, J. L. Atwood. Organometallics 14, 4402 (1995).

15. P. J. Shapiro. Coord. Chem. Rev. 189, 1 (1999). 
16. Y. Ehleiter, G. Wolmershäuser, H. Sitzmann, R. Boese. Z. Anorg. Allg. Chem. 622, 923 (1996).

17. P. Jutzi and A. Seufert. J. Organomet. Chem. 161, C5 (1978).

18. A. H. Cowley, A. Voigt, S. Filipponi, C. L. B. Macdonald, J. D. Gordon. Chem. Commun. 911 (2000).

19. P. Jutzi, D. Kanne, C. Krüger. Angew. Chem. 98, 163 (1986); Angew. Chem., Int. Ed. Engl. 25, 164 (1986).

20. N. S. Rees, D. M. Schubert, C. B. Knobler, M. F. Hawthorne. J. Am. Chem. Soc. 108, 5369 (1986).

21. N. S. Hosmane, P. de Mester, U. Siriwardane, M. S. Islam, S. C. Chu. Chem. Commun. 1421 (1986).

22. H. H. Karsch, U. Keller, S. Gamper, G. Müller. Angew. Chem. 102, 297 (1990); Angew. Chem., Int. Ed. Engl. 29, 295 (1990).

23. (a) M. Denk, R. Lennon, R. Hayashi, R. West, A. V. Belyakov, H. P. Verne, A. Haaland, M. Wagner, M. Metzler. J. Am. Chem. Soc. 116, 2691 (1994); (b) B. Gehrhus, M. F. Lappert, J. Heinicke, R. Boese, D. Bläder. Chem. Commun. 1931 (1995); (c) J. Heinicke, A. Oprea, M. K. Kindermann, T. Karpati, L. Nynlaszi, T. Veszpremi. Chem. Eur. J. 4, 541 (1998).

24. M. Kira, S. Ishida, T. Iwamoto, C. Kabuto. J. Am. Chem. Soc. 121, 9722 (1999).

25. T. Kühler and P. Jutzi. Adv. Organomet. Chem. In press.

26. U. Holtmann, P. Jutzi, T. Kühler, B. Neumann, H.-G. Stammler. Organometallics 18, 5531 (1999).

27. A. Purath, C. Dohmeier, A. Ecker, R. Köppe, H. Krautscheid, H. Schnöckel, R. Ahlrichs, C. Stoermer, J. Friedrich, P. Jutzi. J. Am. Chem. Soc. 122, 6955 (2000).

28. P. Jutzi. Chem. Rev. 86, 983 (1986).

29. P. Jutzi. In The Chemistry of Organic Silicon Compounds, Z. Rappoport and Y. Apeloig (Eds.), Vol. 2, Chap. 35, pp. 2129-2175, Wiley, New York (1998).

30. M. D. Fryzuk, S. S. H. Mao, P. D. Duval, S. J. Rettig. Polyhedron 14, 11 (1995).

31. P. Jutzi, R. Krallmann, G. Wolf, B. Neumann, H.-G. Stammler. Chem. Ber. 124, 2391 (1991).

32. S. Xu, J. Zhang, B. Zhu, B. Wang, X. Zhou, L. Weng. J. Organomet. Chem. 626, 186 (2001).

33. M. Theil. Ph.D. Thesis, University of Bielefeld (2002).

34. P. Jutzi, D. Eikenberg, B. Neumann, H.-G. Stammler. Organometallics 15, 3659 (1996).

35. P. Jutzi and U. Meyer. J. Organomet. Chem. 431, C 29 (1992).

36. P. Jutzi, M. Meyer, S. Opiela, B. Neumann, H.-G. Stammler. J. Organomet. Chem. 439, 279 (1992).

37. M. Schiffer, E. Leiner, M. Scheer. Eur. J. Inorg. Chem. 1661 (2001).

38. P. J. Shapiro. In Group 13 Chemistry - From Fundamentals to Application, P. J. Shapiro and D. A. Atwood (Eds.), ACS Symposium Series 822, pp. 31-48, American Chemical Society, Washington, DC (2002).

39. O. T. Beachley, Jr., M. T. Mosscrop. Organometallics 19, 4550 (2000) and references cited therein.

40. P. Jutzi and U. Meyer. J. Organomet. Chem. 333, C 18 (1987).

41. P. Jutzi. U. Meyer, B. Krebs, M. Dartmann. Angew. Chem. 98, 894 (1986).

42. D. Schröder, H. Schwarz, P. Jutzi, H. Sievers, M. Reiher. Angew. Chem. 111, 3723 (1999); Angew. Chem., Int. Ed. 38, 3513 (1999).

43. J. Dahlhaus, P. Jutzi, H. J. Fienck, N. Kulisch. Adv. Mater. 5, 377 (1993).

44. A. Klipp, F. Hamelmann, G. Haindl, J. Hartwich, U. Kleineberg, P. Jutzi, U. Heinzmann. Chem. Vap. Dep. 6, 63 (2000).

45. K. Dittmar, P. Jutzi, J. Schmalhorst, G. Reiss. Chem. Vap. Dep. 7, 193 (2001).

46. M. Scherer snd T. Kruck. Chem. Vap. Dep. 3, 33 (1999).

47. S. Bensiek, M. Bangel, P. Jutzi. Organometallics 19, 1292 (2000). 
48. (a) P. Jutzi, N. Lenze, B. Neumann, H. G. Stammler. Angew. Chem. 113, 1470 (2001); Angew. Chem., Int. Ed. 40, 1424 (2001); (b) A. Althoff, P. Jutzi, N. Lenze, B. Neumann, A. Stammler, H. G. Stammler. Organometallics 21, 3018 (2002).

49. S. J. Rowan, S. J. Cantrill, G. R. L. Cousins, J. K. M. Sanders, J. F. Stoddart. Angew. Chem. 114, 938 (2002); Angew. Chem., Int. Ed. 41, 898 (2002). 